\title{
Notes on the Histology of a Giant and an Ordinary Form of Plantago
}

\author{
Contributions to Cytology and Genetics from the Departments of \\ Plant-Morphology and of Genetics, Botanical Institute, \\ Faculty of Science, Tokyo Imperial University, No. 49
}

By

\section{Yosito Sinotô}

With 2 Text-Figures

Various cases of chromosome features in relation to a stature of plants have been studied by several authors. The gigantism among some forms of the same species or in the same genus was found in several cases to be closely related with the polyploidy of chromosomes, while in other cases it was shown that no such relation existed. Plantago japonica, a littoral species growing wild in Japan, has its inflorescence axis measuring sometimes more than $100 \mathrm{~cm}$. long and is conspicuously larger in other parts of the body than $P$. major, var. asiatica. Prof. FujII, to whom specimens of the former were handed over by Prof. Nagaoka of the Physical Institute of our Imperial University, who collected them at the coast of Misaki, the Miura Peninsula, suggested to me to examine whether this giant species is a polyploid in comparison with the type species Plantago major or its allies. A cytological study has shown that this giant form, contrary to the expectation, has only half the number of chromosomes found in the above named other species $P$. major, var. asiatica. This notable fact led me to make a closer comparison between the two forms with regard to their histology.

Previous to the description of the aimed observation, some measurements on the three closely allied species will be given in the following table : 
Table I

\begin{tabular}{|c|c|c|c|c|c|}
\hline \multirow{2}{*}{ Plant Name } & \multirow{2}{*}{$\begin{array}{l}\text { Spike length } \\
\mathrm{cm} .\end{array}$} & \multicolumn{2}{|c|}{ Leaf-blade } & \multirow{2}{*}{$\begin{array}{c}\text { Petiole-length } \\
\mathrm{cm} .\end{array}$} & \multirow{2}{*}{$\begin{array}{c}\text { Number of veins in } \\
\text { a leaf }\end{array}$} \\
\hline & & $\begin{array}{l}\text { Length } \\
\mathrm{cm} \text {. }\end{array}$ & $\begin{array}{l}\text { Width } \\
\mathrm{cm} .\end{array}$ & & \\
\hline P. major & 31.5 & $12 *$ & $9 \cdot 4^{*}$ & 13 & $\begin{array}{l}7 \text { Large veins** } \\
2 \text { Small , }\end{array}$ \\
\hline $\begin{array}{l}P . \text { major, } \\
\text { var. asiatica }\end{array}$ & 49.0 & $\mathrm{I} 2.5$ & 9 & 17.5 & $\begin{array}{l}5 \text { Large veins } \\
2 \text { Small , }\end{array}$ \\
\hline P. japonica & 93.0 & $2 \mathrm{I}$ & I3.5 & $2 \mathrm{I}$ & $\begin{array}{l}\text { 7-9 Large veins } \ddagger \\
\text { I-2 Small , }\end{array}$ \\
\hline
\end{tabular}

Although a smaller number of specimens of each species were available, the magnitudes given above, which are average values of measurements on the herbaria of a few mature plants at my disposal, seem to represent the normal relations fairly well. From the above table it will be seen that $P$. japonica is a giant form. The seeds of $P$. major and of $P$. japonica show similar appearences, though they are smaller in size and higher in number than those of $P$. major, var. asiatica. $P$. japonica is edible and cultivated in certain districts in Japan, in which condition, according to Mr. Makino, the plants get to have a larger stature than in the wild. Thus there may be much larger individuals than those on which above measurements were based. In young petioles of $P$. major, var. asiatica and of $P$. japonica, I counted 5-6 larger bundles and about 5 smaller bundles in the former, and about 7 larger and $2-7$ smaller in the latter. These numbers of larger bundles approximately correspond to those of large veins in the leaf of matured plants (see the table I).

When the investigation was begun, the mature plants of $P$. japonica were.difficult to be obtained, so I raised the young plants from seeds in the green house during September I924 to March 1925. The young $P$. major, var. asiatica was collected last winter in the Botanical Garden of the Imperial University and also kept in

* According to Tenopyr's measurements, his specimen of P. major gave $\mathbf{1 7 6 . 0 9}$ $\mathrm{mm}$. and II $\mathbf{1} .06 \mathrm{~mm}$. for the length and width of leaves.15)

* De Candolle1) mentioned 3-5-7 veins.

\ 7-9 veins were counted by Franchet and Savatier.4) 
the green house. This too was not mature. The roots used for the measurements of a cell and nuclear size were taken from these of the two species. As the type species $P$. major is not known growing wild in Japan, its seeds were not at my disposal, so no fresh material could be used for the comparison.

The size of nuclei and cells of $P$. major, var. asiatica and of $P$. japonica was measured respectively in one hundred and fifty cells of their root-tips. The used roots of $P$. japonica were somewhat larger, on the average, than the other. Both materials were fixed in the Flemming's Bonn-solution which was added with some urea, and treated carefully in the same manner. The cells of dermatogen were chosen for measurements in a transitionary region from division tissue to permanent tissue. The microtome sections were cut both transversely and longitudinally. The results are shown in the next table (Table II).

All cells and nuclei were drawn in the same scale with the aid of a camera lucida, the magnification being about I Ioo times. The measurements made on the drawings are shown on the table II in terms of millimeters, so that the real magnitudes in $\mathrm{mm}$. are to be obtained approximately by dividing the numbers given on the table by $\mathbf{I}$ IOO.

Table II.

\begin{tabular}{|c|c|c|c|c|c|c|c|}
\hline \multirow{2}{*}{ Plant Name } & \multirow{2}{*}{$\begin{array}{c}\text { Number of } \\
\text { nuclei } \\
\text { and cells }\end{array}$} & \multicolumn{2}{|c|}{$\begin{array}{c}\text { Average size } \\
\text { of nuclei }\end{array}$} & \multirow{2}{*}{$\begin{array}{c}\mathrm{r}=\text { Average } \\
\text { radius of } \\
\text { nuclei }\end{array}$} & \multicolumn{2}{|c|}{$\begin{array}{c}\text { Average size } \\
\text { of cells }\end{array}$} & \multirow{2}{*}{$\begin{array}{l}\text { Product of } \\
\text { the length } \\
\text { and widh } \\
\text { of cells }\end{array}$} \\
\hline & & Length & Width & & Length & Width & \\
\hline \multirow{2}{*}{$\begin{array}{l}P . \text { major, } \\
\text { var. asiatica }\end{array}$} & $\begin{array}{l}50 \text { nuclei and } \\
50 \text { cells in } \\
\text { longitudinal } \\
\text { sections } \\
\end{array}$ & 8.22 & 6.67 & $\begin{array}{l}r=3.72 \\
r^{3}=51.48\end{array}$ & 18.82 & I6.32 & 307.14 \\
\hline & $\begin{array}{l}99 \text { nuclei and } \\
\text { roo cells in } \\
\text { transvers e } \\
\text { sections }\end{array}$ & 8.35 & 6.18 & $\begin{array}{l}r=3.63 \\
r^{3}=47.84\end{array}$ & 20.84 & 10.63 & 221.53 \\
\hline \multirow{2}{*}{ P. japonica } & $\begin{array}{l}50 \text { nuclei and } \\
50 \text { cells in } \\
\text { longitudina] } \\
\text { sections }\end{array}$ & 7.02 & 5.28 & $\begin{array}{l}r=3.08 \\
r^{3}=29.23\end{array}$ & 19.72 & I 5.73 & 310.2 \\
\hline & $\begin{array}{l}97 \text { nuclei and } \\
\text { Ioo cells in } \\
\text { transvers } \\
\text { sections }\end{array}$ & 6.98 & 5.18 & $\begin{array}{l}r=3.04 \\
r^{3}=28.09\end{array}$ & 22.96 & 10.66 & $244 \cdot 75$ \\
\hline
\end{tabular}

Considering the data of the table II, we see that the average volume of nuclei in $P$. major, var. asiatica is much larger than in $P$. 
japonica, while the products of the length and width of cells in both species are nearly the same. The volume ratio of nuclei in the two species is about I.7:I. The shape of nuclei is nearly spherical, while the cells are irregular cubes. Moreover the three dimensions can not be measured in one section, consequently a highly reliable measure of the volume of each cell is difficult to be obtained. For getting some notion of cell volumes, however, I used the average width of cells in a longitudinal section as one dimension, viz. the hight of cells in a transverse section. The volume ratio of cells thus obtained was $3440.19: 3578.35$, or I : I.04. It will be noticed that the average volume of nuclei in $P$. major, var. asiatica is approximately twice as that in $P$. japonica, while the average cell volumes of both species are almost the same.

Then to get some idea of the chief cause of the giantness of $P$. japonica, further measurements on other somatic characters were made, the result of which is given in the table III.

Table III

\begin{tabular}{|c|c|c|c|c|c|}
\hline \multirow[t]{2}{*}{ Plant Name } & \multicolumn{2}{|c|}{$\begin{array}{l}\text { Average size of } \\
20 \text { stomata of a } \\
\text { leaf, magnified ca. } \\
\text { X I IOO }\end{array}$} & \multirow{2}{*}{$\begin{array}{l}\text { Average num- } \\
\text { ber of stomata } \\
\text { of a leaf, in a } \\
\text { definite area (in } \\
\text { a field of ZEIss } \\
\text { K. I } 2 \times \text { DD) }\end{array}$} & \multirow{2}{*}{$\begin{array}{l}\text { Average num- } \\
\text { ber of upper } \\
\text { epidermal } \\
\text { cells in a difi- } \\
\text { nite area (in } \\
\text { a field of ZEISS } \\
\text { K. I } 2 \times \text { DD) }\end{array}$} & \multirow{2}{*}{$\begin{array}{l}\text { Average number } \\
\text { of palisade cells } \\
\text { in a definite linear } \\
\text { distance (in a dia- } \\
\text { meter of a field of } \\
\text { ZEISS K. I } 2 \times \mathrm{DD})\end{array}$} \\
\hline & $\begin{array}{l}\text { Length } \\
\mathrm{cm} .\end{array}$ & $\begin{array}{c}\text { Width } \\
\mathrm{cm} .\end{array}$ & & & \\
\hline $\begin{array}{l}P . \text { major var. } \\
\text { asiatica }\end{array}$ & 36.6 & $2 \mathrm{I} .5$ & 5.4 & I 5 & 9.6 \\
\hline P. japonica & 31.0 & 22.0 & 10.0 & $3 I$ & 10.0 \\
\hline
\end{tabular}

The measurements shown in the table III were made on the very individuals of $P$.japonica from which the material was taken before for the measurements of the dimensions of cells and nuclei. They have been cultivated outdoors for about two months since the end of March. They had still no spike, and their leaves were seemingly not 
full grown; still some leaves though of a small size, were nearly in the mature state of development, as far as the development of their stomata showed. A number of mature individuals of $P$. major, var asiatica were collected in the beginning of June in the Botanic Garden, and their leaves and spikes were used for the measurements given in the table III. For the comparison of the somatic characters, the leaves of both species in about the same developmental stage were selected, the tissues being chosen from the corresponding part of the organs.

In the table III we may see that the size of cells in $P$. japonica is generally smaller than that of the other species. According to JoNEs $^{10)}$, though he gave no measurements, the leaves of Digitalis purpurea were larger and broader than those of $D$. grandiflora, while the cells and stomata of the latter were larger than those of the former. This seems to be a parallel case with that of Plantago. At any rate, as far as my measurements on the tissues used are

Average number of cells Average number of cells in a linear row of $\frac{1}{2} \mathrm{~cm}$. in a linear $\mathrm{row}$ of $\frac{1}{2} \mathrm{~cm}$.

\begin{tabular}{|c|c|c|c|}
\hline length of & petiole & length & a spike \\
\hline $\begin{array}{l}\text { At the re } \\
\text { gion above } \\
3-3 \frac{1}{2} \mathrm{~cm} \text {. } \\
\text { from the } \\
\text { base }\end{array}$ & $\begin{array}{l}\text { At the re } \\
\text { gion above } \\
\text { IO-I } 2 \text { cm. } \\
\text { from the } \\
\text { base }\end{array}$ & $\begin{array}{l}\text { At the re } \\
\text { gion above } \\
\text { ro-r } 5 \mathrm{~cm} \text {. } \\
\text { from the } \\
\text { base }\end{array}$ & $\begin{array}{l}\text { At the re- } \\
\text { gion above } \\
20 \mathrm{~cm} \text {. from } \\
\text { the base in } \\
P . \text { major, } \\
\text { var. asiatica } \\
\text { and 5ocm. in } \\
P . \text { japonica }\end{array}$ \\
\hline $33 \cdot 4$ & 22.0 & 21.5 & 25.0 \\
\hline 33.6 & & $18.0^{*}$ & $28.0 *$ \\
\hline 3 I. C* & $34.0 *$ & & \\
\hline
\end{tabular}
pared with the other with
smaller nuclei ; viz. in $P$. major, var. asiatica, the haploid chromosome

concerned, the giantness of P.japonica is to be ascribed to the high number of cells in the corresponding parts or organs of this plant.

The examination of the chromosome number and the nuclear size in both species shows that the one with larger nuclei has the double number of chromosomes when com$*$ These measurements were obtained from one of the largest dried specimens
of the plant. 
number is $12^{*}$ and the diploid $24^{*}$ (Fig. I), while the nucleus of $P$. japonica has 2 chromosomes in the root-tip cell (Fig. 2). The shape and size of somatic chromosomes in both species are generally alike, though the chromosomes shown in Fig. 2 seem to be

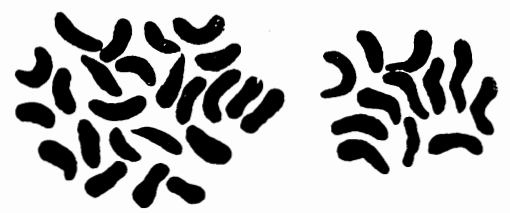

Fig. I

Fig. 2 somewhat smaller than those of Fig. I. Ekstrand ${ }^{2)}$ reported the chromosome numbers of five species of Plantago. According to him, $P$. major has the 6 haploid and 12 diploid chromosomes. However, owing to the lack of any description and figures about the size of somatic chromosomes of this species, I can not make any comparison between this and the two other species I have examined.

Of various instances hitherto reported on the relation between the chromosomes and the stature of plants, a provisional classification may be given : I) chromosome number same, size of chromosome as well as of nucleus alike, cell size smaller (Hedera helix conglomerata, a dwairf form:** H. helix typica ${ }^{12)}$ ), II) chromosome number same, cell size alike ${ }^{15)}$ (Plantago major $^{2)}:$ P. lanceolata $\left.^{11)}\right)$, III) Chromosome number same, chromosome and cell size larger (Primula sinensis, var. gigas: P. sinensis ${ }^{(i)}$; Phragmites communis, var. Pseudodonax, a giant form : $P$. communis ${ }^{16)}$ ), IV) chromosome number same, body size dwarf (Oenothera nanella: O. Lamarckiana, etc.), V) chromosome number larger, nuclear or cell size larger (gigas-,hero-races ; Oenothera gigas: O. Lamarckiand ${ }^{5)}$; gigas-form in Solanum ${ }^{20)}$; Hedera helix hibernica: H. helix typica ${ }^{12)}$; some forms in Bryum, Mnium and Amblystegium***; varieties of Athyrium Filix-foemina ${ }^{3)}$; Taraxacum albidum:T. platycarpum $^{13)}$; triploid forms in Canna $^{18)}$ and Morus ${ }^{14)}$; multiploid forms in Chrysanthemum $\left.{ }^{19}\right)$, VI) chromosome number larger (double); a) chromosome size alike, nuclear size larger (?) (Erigeron una'askensis, a dwarf form:E. eviocephalus ${ }^{8)}$ ), b) chromosome size alike, nuclear

* These chromosome numbers I have determined agree with Mryajı's determination.9)

** The symbol: used hereafter, whenever put in branckets, means "in comparison with.",

*** Marciial, El. and EM. I906-i I (after Tischler ${ }^{17}$ ) 
size larger, cell size larger or alike (Plantago major, var. asiatica, ${ }^{*}$ a smaller form : $P$. japonica), VII) chromosome number larger, chromosome size smaller, body size smaller (Rumex acetosella** : R. acctosa; some species of Carex $\left.{ }^{7}\right)$. There are also exceptions which are not included in this classification.

Although the results of my measurements in the present case of Plantago may not be conclusive, it may be with a certain confidence concluded that the size of somatic chromosomes in the two forms of Plantago is alike, and the one, a smaller form possessing double the number of chromosomes found in the larger form, has larger nuclei, and that the cell size in the larger form is generally smaller than that in the other, or in certain cases it is nearly alike in both forms, as far as the measurements on the tissues employed are concerned. Accordingly the giantness of $P$. japonica is due to the larger number of cells in the corresponding part or organ of this form. Thus the present case of Plantago forms a subclass of the class VI) of the above classicication.

In concluding I desire to express my sincere thanks to Prof. $\mathrm{K}$. FujII for his valuable advice and criticisms during the course of this work.

Botanical Institute, Faculty of Science, Tokyo Imperial University June, 1925

* P. major, var. asiatica has double the number of chromosomes of P. major, but the size relation of chromosomes as well as of nuclei and cells cannot be made out, as the data regarding the latter plant are wanting as mentioned before.

* Roti, H. 1906 (after Holmaren ${ }^{8}$ ) 


\section{Bibliography}

I De Candolle, A. (I852) Prodr. 13, I

2 Ekstrand, H. (19I8) Sv. bot. Tidskr. 12

3 Farmer, J. B. and Digby, L. (I907) Ann. of Bot. 21

4 Franchet, A. et Savatier, L. (I879) Enum. P1. Jap. 2

5 Gates, R. R. (I909) Arch. f. Zellf. 3

6 Gregory, R, P. (I909) Proc. Cambridge Phil. Soc. 15

7 Heilborn, O. (I924) Hereditas 5

8 Holmgren, J. (I9I9) K. Sv. Vet. Akad. Handl. 59

9 Ishikawa, M. (I9I6) Bot. Mag. Tokyo, 30

IO JONES, W. N. (I9I2) Journ. Genet. 2

I I NĚmec, B. (I IIo) Das Problem d. Befruchtungsvorgänge usw.

I2 Oенм, G. (I924) Beih. z. bot. Centralbl. 40

I3 Osawa, I. (I9I3) Arch. f. Zellf. 10

14 Osawa, I. (I9I6) Bull. Imp. Sericult. Exp. Stat. Japan, 1

I5 Tenopyr, L. A. (I918) Bull. Tor. Bot, Cl. 45

I6 Tischler, G. (I9I8) Ber. d. d. bot. Ges. 36

17 Tischler, G. (I920-I) Allgemeine Pflanzenkaryologie

I8 Tokugawa, Y. and Kuwada, Y. (I924) Jap. Journ. Bot. 2

I9 Tahara, M. (I92I) Journ. Coll. Sci. Imp. Univ. Tokyo, 43

20 Winkler, H. (I9I6) Zeitschr. f. Bot. 8 